\title{
Interactive comment on "Development of a methodological framework for the assessment of seismic induced tsunami hazard through uncertainty quantification: application to the Azores-Gibraltar Fracture Zone" by Vito Bacchi et al.
}

Anonymous Referee \#3

Received and published: 2 August 2018

The manuscript aims to present a method to assess tsunami hazard and its uncertainties using sensitivity analysis and meta-modeling technique. The authors then applied their method to a case study, identifying a source area (west of Gibraltar strait) and a target area (French Atlantic coast). Even though the methodology sounds very interesting to support probabilistic tsunami hazard assessments, in my opinion the paper could not be published in its present form.

Printer-friendly version

Discussion paper 
As major comments I found the following issues:

1) The manuscript lacks some important references on one of the main topic of the manuscript itself: quantification of uncertainties in tsunami hazard assessment. Several works faced this topic (among others, Sorensen et al, 2012, Horspool et al, 2014, Davies et al., 2016, Lorito et al., 2015, Selva et al., 2016) using probabilistic approaches and proposing methods to strongly reduce computation costs. Also approaches to develop databases based on combination of elementary sources to speed up tsunami modeling have been proposed (Miranda et al, 2015 and Baptista et al 2017), even with the quantification of the associated uncertainty (Molinary et al., 2016). I think that the manuscript should be rethought considering the existing framework.

2) I am a bit lost between the explanation of the method and how it was applied for the case study. In particular, the environment Promethee seems to me the glue of everything, so I found strange that it was quickly mentioned only in section 3 . I would suggest to present what Promethee is, which module contains, how is used in this work and what the authors customized in the frame of Promethee for their scopes. For example, I did not understand subsection 2.2: why using a subsection to describe a module that was not used (if I understand well), i.e., the Monte Carlo method originally implemented in Promethee? Authors could state that uncertainty propagation used in Promethee environment for this study is modeled using an external package based on kriging. My suggestion is to rearrange section 2 and 3 in a clearer way.

3) Even though I understand that the aim of the paper is illustrative of the method, I have some doubts about the design database: the number of considered scenarios (about 5,000 ) seems to me relatively low with respect the number of the considered parameters and their large variability. My concern is that a too rough sampling of input parameters could introduce bias in the design of the meta-model. I would ask to authors to address this issue.

4) The work often refers to the meeting communication by Antoshchenkova et al.,

Printer-friendly version

Discussion paper 
(2016) which cannot be verified by readers. This should be avoided in a peer-reviewed manuscript. When needed, important element from that work should be reported directly here.

5) About tsunami modeling: linear or non-linear shallow water equations have been used? This is not specified in the text, however depth of tide gauges is $40 \mathrm{~m}$ or less (and less than $30 \mathrm{~m}$ for 3 stations), where non linearity effects become very strong and cannot be neglected.

6) I did not understand if magnitude is uniformly sampled as stated in the text (page 14, line 17), since in figure 9a the distribution seems very different. Authors should clarify this point.

7) Even though the manuscript is illustrative, maybe to make the case study less far from something more realistic, the authors could use a magnitude distribution from catalogs

8) The numbering of figures and tables should be adjusted with respect the order in which they are mentioned in the text.

Other comments:

1) Page 2, lines 28-30: If I understand well the sentence, I disagree with the authors, since I would say the opposite: if the knowledge on the area is poor, a probabilistic approach can at least quantify this level of uncertainty, whereas deterministic approaches hardly can catch what is unknown and they could suffer of relevant bias in the hazard analysis.

2) Page 3, lines 13: The authors are referring to deterministic approaches only or to probabilistic ones as well?

3) Page 17, line 17: I cannot really understand the meaning of the sentence "for a given magnitude, a tsunami generated by a well located-oriented fault would be potentially more hazardous". Well located-oriented with respect what? I would remove the sen-

Printer-friendly version

Discussion paper 
tence, since it is already stated that the analysis suggests that position and orientation (strike/rake) for two of the stations are very relevant for hazard assessment. I

4) Figure 3: I guess that tick labels for longitude axis should be $W$ instead $O$

\section{References}

Interactive

Baptista, M. A., Miranda, J. M., Matias, L., \& Omira, R. (2017). Synthetic tsunami waveform catalogs with kinematic constraints. Natural Hazards and Earth System Sciences, 17(7), 1253.

Davies G, Griffin J, Løvholt F, Glimsdal S, Harbitz C, Thio HK, Lorito S, Basili R, Selva J, Geist E, Baptista MA: A global probabilistic tsunami hazard assessment from earthquake sources, Geological Society, London, Special Publications, 456, 23 February 2017, https://doi.org/10.1144/SP456.5, 2016

Horspool, N., Pranantyo, I., Griffin, J., Latief, H., Natawidjaja, D. H., Kongko, W., Cipta, A., Bustaman, B., Anugrah, S. D., and Thio, H. K.: A probabilistic tsunami hazard assessment for Indonesia, Nat. Hazards Earth Syst. Sci., 14, 3105-3122, https://doi.org/10.5194/nhess-14-3105-2014, 2014.

Lorito, S., Selva, J., Basili, R., Romano, F., Tiberti, M. M., and Piatanesi, A.: Probabilistic Hazard for Seismically-Induced Tsunamis: Accuracy and Feasibility of Inundation Maps, Geophys. J. Int., 200, 574-588, https://doi.org/10.1093/gji/ggu408, 2015.

Miranda, J. M., Baptista, M. A., and Omira, R.: On the use of Green's summation for tsunami waveform estimation: a case study, Geophys. J. Int., 199, 459-464, 2014

Molinari, I., Tonini, R., Piatanesi, A., Lorito, S., Romano, F., Melini, D., Vida, J. G., Macias, J., Castro, M., and de la Asuncion, M.: Fast evaluation of tsunami scenarios: uncertainty assessment for a Mediterranean Sea database, Nat. Hazards Earth Syst. Sci., 16, 2593-2602, https://doi.org/10.5194/nhess-16-2593-2016, 2016

Selva, J., Tonini, R., Molinari, I., Tiberti, M. M., Romano, F., Grezio, A., Melini, D.,

Printer-friendly version

Discussion paper 
Piatanesi, A., Basili, R., and Lorito, S.: Quantification of source uncertainties in Seismic Probabilistic Tsunami Hazard Analysis (SPTHA), Geophys. J. Int., 205, 1780-1803, NHESSD https://doi.org/10.1093/gji/ggw107, 2016

Sørensen M.B., Spada M., Babeyko A., Wiemer S., Grunthal G.: Probabilistic tsunami hazard in the Mediterranean Sea, Journal of Geophysical Research, 117, https://doi.org/10.1029/2010JB008169, 2012.

Interactive

comment

Interactive comment on Nat. Hazards Earth Syst. Sci. Discuss., https://doi.org/10.5194/nhess2018-142, 2018. 